\title{
Groceries Retail Prices Monitoring as a Tool of Socially Oriented Marketing in Russia
}

\author{
Roman Sidorchuk ${ }^{1}$
}

Irina Skorobogatykh ${ }^{1}$

Janna Musatova ${ }^{1}$

\author{
Valeriy Yemets $^{2}$
}

Rezeda Valiullina ${ }^{3}$

\author{
${ }^{1}$ Department of Marketing, Plekhanov Russian University of Economics \\ 2 Department of Political Science and Sociology, Plekhanov Russian University of Economics \\ ${ }^{3}$ Department of Management and Marketing of Sport Industry, Plekhanov Russian University of Economics. \\ Moscow, Russian Federation, Correspondence: Roman Roaljovich Sidorchuk, Novoslobodskaya ul., dom 62 \\ korpus 19, kv.306, Moscow, Russian Federation, 127055. E-mail: Sidorchuk.RR@rea.ru
}

\section{Doi:10.5901/mjss.2015.v6n5s4p457}

\begin{abstract}
Marketing in the social products sector has peculiar features. The low marginality in this group of products is compensated to trading companies by the preferential treatment of the government and a positive image in the society. The price monitoring methodology for the analysis of social groceries offer becomes of particular importance. This article is intended to contribute to better understanding of the capabilities and limitations of the price monitoring mechanism applied to the offer of socially important food products. Based on the classical approach to the methodology of price monitoring, we selected and justified in this study a sample of social food products having a high value throughout the vast territory of Russia. To identify the role of the various channels of goods, we selected a sample of surveyed chain and disperse (independent) stores. The obtained results led to the conclusion that the Russian retail trade is highly volatile in terms of the minimum prices for social food products. The high level of price volatility related to such products may reflect the current crisis phenomena in Russia.
\end{abstract}

Keywords: marketing, sanctions, crisis, price volatility, prices monitoring, Russia, socially important goods, retail stores

\section{Introduction}

The food market in most segments is characterized by relatively low elasticity of the demand, which in the circumstances of the financial crisis makes it one of the most stable and attractive. Price is a key characteristic of products, accumulating information on the factors of production and products' quality. In addition, in the conditions of the imperfect market, price is often a subject of speculation. At the same time, in literature (Aksoy \& Dikmelik, 2008; Ravallion, 1989, Seshan \& Umali-Deininger, 2007; Byerlee, Myers, \& Jayne, 2006; Ivanic \& Martin, 2008), there is a certain consensus regarding the attitude to the increase in food prices for socially disadvantaged categories of the population. In this regard, we can say that the trend model of the current state of the consumer market in Russia, seriously pressing on it, is the decrease in the purchasing power of the population, which most actively manifests itself in the most disadvantaged population groups. In turn, the authors believe that the role of social marketing increases in these circumstances. The tasks and role of marketing, especially of the non-profit and social sectors, are ambiguously approached in the scientific literature and in the business practice. It is particularly difficult to determine the place of marketing and its role, methodology, and tools in the production and sale of branded products and products of the low price segment. These issues are most relevant in the circumstances of non-market constraints that influence the processes of international trade.

A significant part of the population of Russia is on the verge of physical survival, providing only the minimum standards of consumption. For example, the report of the Institute of Sociology "Poverty and inequality in modern Russia: 10 Years Later" (2013) presents data that remain relevant even today. The officially established "poverty line" in Russia (as of 2013) is 6,705 rubles per month: 2,412 rubles for food; 1,057 rubles for all non-food products (including medicines), 2,754 rubles for all services (including housing services and transport); the rest for taxes and other obligatory payments and fees. In turn, according to the results of the population survey, which are provided in this report, the minimum level of 
income, beneath which there is the poverty line, is 8,848 rubles. Since 2003 , the proportion of poor people dropped from 66 to $30 \%$ of the population (from 2003 to 2013), which is still a very large share. In 2003 and 2013, 20\% of Russians lived as poor, even though their incomes were above the minimum level of subsistence. $4 \%$ of the population, or about 6 million people, form the group of deep and chronic poverty, which is fundamentally different from other forms of poverty. Having a job does not protect the Russians from poverty. In many young families with children, in which both parents work, the per capita income is below the official one. Thus, in these circumstances of the low per capita income for a large part of the population, food consumption is extremely low, and there is a serious threat of its further decline. One of the main reasons for the low consumption of staples is their unaffordable price. Under these conditions, it is particularly important to study the trends of changes in retail prices for socially important groceries. To solve this problem, the authors have proposed a number of hypotheses:

1) In the current economic situation in Russia, high volatility will be observed in the structure of minimum prices for socially important food products.

2) The minimum prices for food products of the same category of socially important food products will be lower in chain stores, but not in the dispersed (separately located, independent, not belonging to a chain) ones.

\section{Literature Review}

In the Soviet Union and Russia, marketing emerged as a concept and as an academic discipline in universities in the late 1980s due to the economic reforms (perestroika). But the term and percept of marketing in the USSR existed even earlier, because as early as in 1976, a marketing section of the Chamber of Commerce of the USSR was organized, the members of the board of which were engaged in the promotion of marketing knowledge as lecturers and as the authors of articles in collections published by the marketing section. In addition, the marketing section made an important contribution to the establishment of professional associations: the Russian Marketing Association, the Russian Association of Managers, as well as to the development of educational standards for training professional marketing specialists for the Russian market (Skorobogatykh \& Saginova, 2005). Despite the rapid and wide spreading of the marketing percept in Russia, since perestroika, the growth of interest of commercial companies to the concept of marketing and to improving the skills of managers, including through self-education and reading the growing number of marketing books, which were appearing in Russia in the 1990-2000s, however, the use of marketing and the experience of its use in the field of public (social) services remains extremely poor so far (Skorobogatykh \& Saginova, 2008).

In this context, the use of the marketing methodology offers significant opportunities for the control interventions of the government, public organizations, and for the development of a strategy of "social responsibility" by private commercial companies. Price monitoring is one of the most common methods to determine the number distribution and price volatility. In literature, the issue of food prices' changes is often associated with the issue of the ratio of net food buyers and buyers that are food producers (rural population). Authors of some works show convincing evidence that the increase in food prices, regardless of the ratio of the said food consumers, will lead in the short term to the absolute poverty growth. In addition, the authors note that often various forms of restrictions, the effect of which is ambiguous, are a form of protection from the rising food prices (Ivanic \& Martin, 2014). On the other hand, some studies have demonstrated that the increase in food prices can act as a growth driver in the agribusiness (Benson et al., 2008). In these studies, based on the analysis of the effects of food crises in some countries, it is noted that in the countries where the impact of rising food prices is of crisis nature, politicians often do not have sufficient information to assess the possible consequences for their country, and to implement fully scientifically substantiated and conscious actions. As an example, the authors examine the impact of price control on the subsequent food product reproduction. The main result of this limitation will be the declining production of food products, which are in the embargo list. In any case, the role of regular monitoring of prices for the goods intended for socially poorly protected groups of the population is essential for decision-making. This thesis is substantiated by several authors (Cuesta, Htenas, \& Tiwari, 2014) who argue that despite the fact that there are different factors influencing food crises and requiring particular attention (such as food culture, presence and operation of food markets, climate, conflicts, level of population's income and systems of its social protection, and so on), food prices constitute a critical factor affecting the food security. Price analysis is essential for the company strategy, as well. Researchers (Coissard \& Carlos, 2011) who considered the issue of the strategies for pricing of products that are not perfect substitutes came to interesting results. The authors' conclusions about the alignment of prices, based on the price monitoring, can be applied to socially important goods, the price elasticity of which is very significant, and there is a relationship of prices for products, which are not substitutes. The importance of monitoring prices for food products intended for the socially disadvantaged groups of the population is emphasized in the studies of social unrests caused by the rising prices in times of crises (Schneider, 2008; Bush, 2010; Berazneva \& Lee, 2011). As 
shown by some authors (Bellemare, 2014), the volatility of food prices reduces social tensions and gives a greater social impact than a simple price cut. In turn, the strategy "pricing based on 'social prices' for commercial companies" leaves open the matter of the added customer value (Sidorchuk, 2015).

\section{Methodology}

In marketing, there are different approaches to the selection of price monitoring points. With account of the current difficulties in identifying the actual price, which the retail traders pay to receive food from wholesale distributors, and the existing cases of statistical information distortion, the authors selected the method of direct monitoring of retail prices. This method relates to methods of qualitative research, and consists in collecting primary data through monitoring the objects under study and recording all facts relevant in terms of the set goals. In marketing, the monitoring method is used to solve a variety of tasks.

The peculiar feature of this study is that not the consumer is monitored, but the prices for a certain range of food products. The key issue of the research was the selection of a sample of retail stores and a sample of food products to monitor. In selecting the sample of food products to monitor, the study authors were guided by the existing legislative documents defining the range of products included in the "market basket." The term "market basket" describes the minimum set of commodities and services that are objectively necessary to meet the priority needs of a person and are required to sustain living activities and preserve the health of a person. The optimum composition of the "market basket" is formed based on the scientifically justified standards of people's consumption and enacted by legislative documents (Federal Law of the Russian Federation "On the market basket" dated 03.12.2012 \#227-FZ). The market basket in the first place includes food products, which in Russia are about $36 \%$ of the costs in the specified minimum income per capita.

Table 1 shows the commodity units of the range, reflecting, according to the researchers, the main content of the food categories included in the "market basket." To generate a list of products, we used the existing state regulations and the empirical experience of researchers. The authors of the study did not target a representative reflection of any brands or manufacturers. The observers had the task to record the presence or absence of a product in Table 1 on nominal (dichotomous) scale. Then, the task was assigned to quantify the minimum price for $1 \mathrm{~kg}$ (1 liter for liquid food products, 10 pcs. for eggs) using the absolute scale. The price was converted to bring the presented commodities to a single weight number regardless of the dimensions of the package.

Table 1.The list of food products range subject for observation

\begin{tabular}{cl}
\hline No. & Product category \\
\hline 1 & Rye-wheat bread \\
2 & Long loaf \\
3 & Pasta \\
4 & Buckwheat \\
5 & Polished rice \\
6 & Potatoes \\
7 & Cabbage \\
8 & Apples \\
9 & Sugar \\
10 & Chicken meat \\
11 & Sterilized drinking milk (1 liter). \\
12 & Fresh frozen fish \\
13 & Sunflower oil \\
14 & Wheat flour \\
15 & Black tea \\
16 & Egg (10 pcs.) \\
17 & Frankfurters \\
\hline
\end{tabular}

The research geography assumes conducting 3 waves of monitoring in 13 Russian cities in 2015 (including Moscow), involving more than 250 students of the Plekhanov Russian University of Economics. The choice of cities for the research was determined by the technical feasibility to carry it out (whether there are branches of the Plekhanov University in these cities). The mentioned geography of the research limits the geographical representation of the results, but the researchers did not target to ensure this kind of representation. 
An important aspect of the research is the sample of retail stores. For cities with a population of 1 million people, a sample of 250 monitoring points (retail stores) in each city was selected based on the proven technique (Kiselev, 2003; Kiselev et al., 2014). For Moscow, the sample of monitoring points included 600 stores. The basis of the sample selection in the city of Moscow was the hypothesis of equal representation of chain and independent stores. This hypothesis is based on the data of the Department of Trade and Services of Moscow (2014), from which it is clear that in the 3rd quarter of 2014 in Moscow, there were 20,500 fixed site chain and independent retailers. Herewith, their number increased since 2013 by 564 food stores. The share of chain trade in Moscow is about 40-45\%, taking into account that the stagnation in the development of chain retail trade resulted in the non-increase in their share in 2014, and the stability of the dispersed (independent) retailers did not cause any reduction in their number in Moscow. Consequently, we can take the share of each retail format in the sample as $50 \%$.

In this context, we took up the quota of monitoring points for the chain trade represented in Moscow based on the proportion of the turnover of these chains according to the "Rating of chain retail trade" (2015). The sample results are shown in Table 2.

To ensure the relevance of the monitoring results, we intended to monitor them in the interval of 2-4 days in each wave of the research.

Despite that monitoring relates to qualitative market research methods, the data obtained during the "field" work can be quantified and summarized (Efimova et al., 2015). At the same time, it should be noted that the study has some common restrictions. The main restrictions are set by the quota method of selection of the monitoring items (the range of groceries and retail stores - the monitoring points). Despite the fact that this method gives results similar to the probability sampling, it is not possible to estimate the statistical error margin of the research. Another important restriction is the measurement of the price index excluding the seasonal factor.

Table 2. Quantitative distribution of the monitoring points (chain trade organizations)

\begin{tabular}{ccc}
\hline No. & Chain retailer (brand) & The number of monitoring points \\
\hline 1 & "Magnit" & 80 \\
2 & X5 RG ("Pyatyorochka", "Perekryostok") & 80 \\
3 & "Auchan" & 12 \\
4 & "Metro" & 5 \\
5 & "Dixy" & 30 \\
6 & "Lenta" & 5 \\
7 & "Sedmoy Kontinent" & 10 \\
8 & "Monetka" & 10 \\
9 & "SPAR" & 10 \\
10 & "Kopeyka" & 15 \\
11 & "Kvartal" & 5 \\
12 & "Billa" & 8 \\
13 & "Magnoliya" & 30 \\
\hline
\end{tabular}

\section{Results}

In this article, because of the size limitation, we provide only some of the results obtained in the course of price monitoring in Moscow. Figure 1 shows the minimum prices for the studied group of food products recorded at the time of the study ("market basket"). 


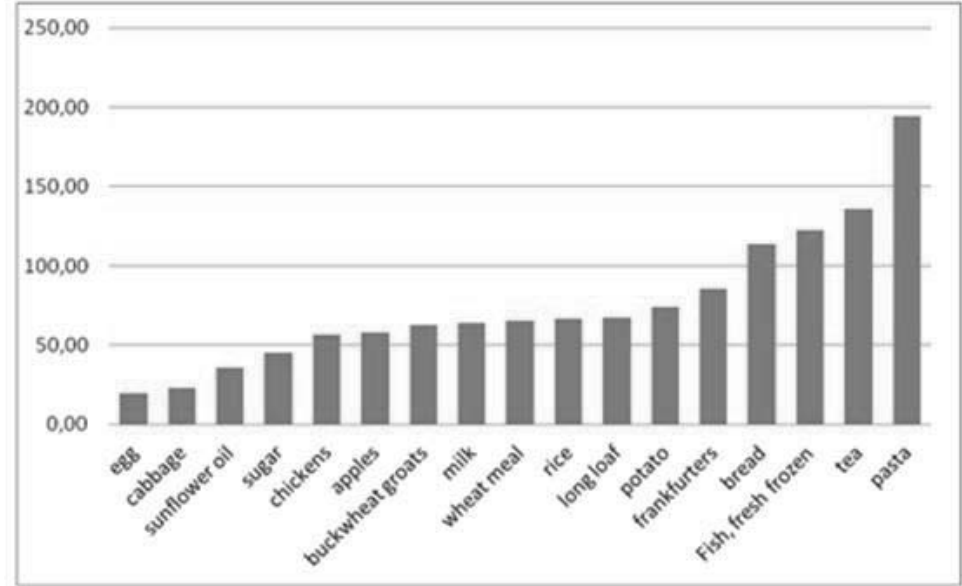

Figure 1. The minimum retail prices for the studied range of products

Due to the fact that the study of minimum retail prices in Moscow was held for the first time, there are no comprehensive statistical data or reliable data of other studies, which would allow comparing the results with previous periods. The authors plan to perform some more research "waves" to obtain the data on the further price changes. At the same time, based on the sample comparison with the existing data on the prices for certain categories of goods using the Rosstat's database (2015) for 2013-2014, we can conclude that the current prices exceed the prices of the late 2013 approximately by $30 \%$. Herewith, we should note that in contrast to our research, the Rosstat's database contains not minimum, but average prices. Given the fact that inflation was planned in 2014 at $6 \%$, and its actual value according to the Ministry of Finance of Russia amounted to $11.4 \%$, we have an additional non-inflationary price growth of at least $20 \%$. The study results demonstrate that the maximum price for the "Milk" product category (among the identified minimum retailers' prices) among chain stores and convenience stores was recorded in the chain shop "Magnolia" and equaled to 68 rubles 82 kopecks; the minimum average price was recorded in an independent store and equaled to 40 rubles 59 kopecks. The lower limit of prices for pasta was approximately equal at chain and independent stores, with the highest price noticed in chain stores. This averages values of prices in independent retail stores for this product category are $20 \%$ higher than in chain stores. The minimum size of the fixed price was 9 rubles 19 kopecks in a chain store "Metro", and the maximum price of 185 rubles was recorded in an independent store. For the product category "Flour", the price per kilogram was between 27 rubles 57 kopecks (chain "Lenta") and 55 rubles 75 kopecks (Zelyony Perekrestok). Independent retailers had the average price 45 rubles 22 kopecks, and chain retailers - 36 rubles 62 kopecks. In turn, the price of potatoes, which are traditionally considered the main vegetable garnish in Russia, were distributed between the chain and independent retailers as follows: the average minimum price in chain stores was 34 rubles 15 kopecks, and in independent stores - 39 rubles 26 kopecks. The retail prices for sunflower oil, which is Russia's most popular vegetable oil, had the following minimum values: at chain retailers - 70 rubles 72 kopecks, at independent retailers -80 rubles 89 kopecks. There is no doubt that the results of the numerical distribution of the minimum prices for buckwheat are of particular interest. Buckwheat is traditional Russian food. At the time of the study, the minimum price of 1 kilogram of buckwheat was recorded in "Magnit" stores - 26 rubles, and the maximum price - 146 rubles — in an independent store. The average price in chain stores was 61 rubles 43 kopecks, in independent stores - 69 rubles 74 kopecks. The minimum prices for chicken meat, which is almost the only supplier of protein for socially vulnerable groups of the population, amounted to 46 rubles 90 kopecks ("Magnit"), and the maximum ones - 270 rubles in an independent store. 


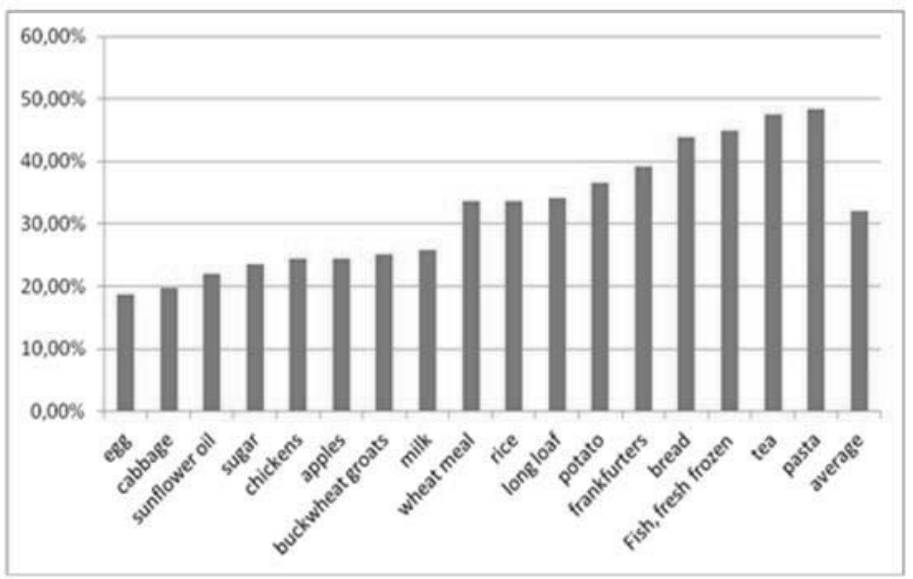

Figure 2. Average market volatility of minimum retail prices

In turn, the diagram (Figure 2) shows the volatility of the obtained minimum prices. Previously, the volatility of the minimum prices in Moscow had not been studied. A visual analysis of the chart enables us to conclude that the greatest volatility is demonstrated by the product categories, such as pasta, tea, and frozen fish. The minimum price volatility was observed with respect to eggs, frankfurters, and sunflower oil. Price volatility is noticed in various stores of the same chain, as well as in a variety of chain and independent stores.

In turn, one of the key indicators for the analysis of the market state is the bread price. Bread is historically the most important staple in Russia. Therefore, the bread prices are always in the area of special focus of the society and the government. Figure 3 shows the volatility of the minimum prices for bread in chain stores. The price ranges between 11 and 28 rubles.

The numerical distribution of volatility of the prices for the studied food products in major chains represented in the diagram (Figure 3) reflects the management structure of these chains. The chains Magnolia, SPAR, X5, and Lenta provide their store managers with more opportunities for independent regulation of prices, than other chains do.

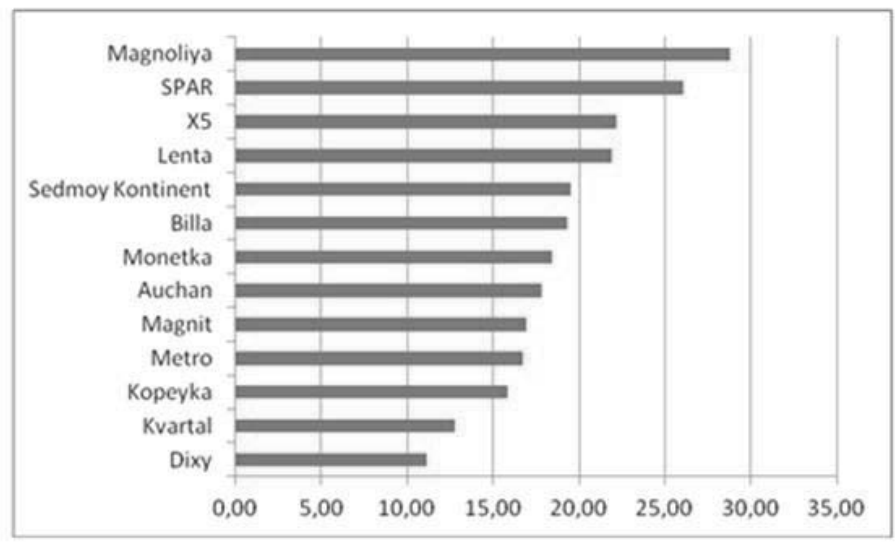

Figure 3. Volatility of the minimum prices for bread in chain stores 


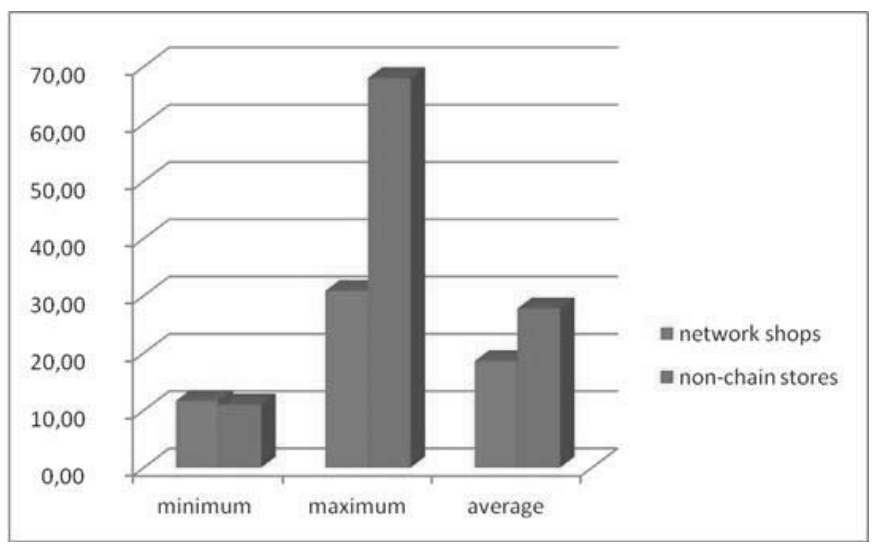

Figure 4. The ratio of the minimum, average, and maximum prices for bread in the chain and independent stores

A visual analysis of the diagram of the proportion of minimum, average, and maximum prices for bread in the chain and independent stores (Figure 4) allows concluding that the minimum prices are approximately the same (the difference is $5.8 \%$ ). At the same time, the average prices in chain and independent stores differ by $49.4 \%$ and the maximum onesby $120.4 \%$.

An important result of the study, requiring separate interpretation is the revealing of the problem of some products' absence from the "food basket" in chain and independent retail stores. For example, the item "frankfurters" at the time of the study was not available in $17 \%$ of independent stores. As for pasta, it was not available in $12 \%$ of the stores in Moscow. And as for tea, it was not represented in just $2.7 \%$. This is not an evidence of "deficit" or insufficiency of such staples in general. We should only mention it as the non-availability of such goods in the low price category. As for chain retailers, the items of the "food basket" group were not available in a small number of stores (less than 5\%). The numerical distribution of the minimum prices across the districts of Moscow shows interesting results. For example, according to the obtained results, the prices in independent stores in the center and west of the city are lower than in chain stores. Herewith, it is impossible to make an unambiguous conclusion about stronger competition between shops in the center or in the west of the city.

\section{Conclusions}

The study reflects the specific situation related to the period of recession (or turbulent economic conditions) obviously affecting the prices for socially important food products.

An analysis of the results of the first wave of monitoring the prices for the socially important food products in retail stores in Moscow allows us to draw the following conclusions. The resulting volatility of the minimum prices for products in the "market basket" is $32.09 \%$, which indicates a crisis emerging in the market after the sharp devaluation of the ruble and the enactment of the food embargo against the EU. We assume that the high volatility is caused by the attempts of market participants to offset their losses caused by the ruble devaluation. Primarily, the volatility is due to the actions of independent stores. The reaction of independent retail stores to any market developments is faster than that of chain stores. This is because the majority of them are small and medium-sized stores, the owners of which are directly involved in the business and can make quick, sole decisions. The share of independent retailers is rather large in Russia and its behavior has a significant impact on market prices. This is confirmed by the distribution of bread prices in chain and independent stores as shown in Figure 4.

The obtained result confirmed the proposed hypothesis that high volatility will be observed in the structure of minimum prices for socially important food products. The hypothesis proposed by the authors that the minimum food prices the same category of socially important food products will be lower in chain stores, than in dispersed stores, was not fully confirmed. As we can see in the diagram (Figure 4) displaying the results of the analysis of the range of minimum prices, the lowest bread prices were found not in chain stores, but in the dispersed ones, while the average price over the entire minimum price range were lower in chain stores. At the same time, the minimum average results demonstrate their lower level in chain stores. 
An interesting result obtained in the study is the absence of a number of goods from the research list of independent retail stores. We assume that this is the result of a "washout" of cheap goods from the assortment matrix caused by their low marginality and fear of retailers to order this product due to its increasing price. The results do not allow us to analyze the situation with the minimum prices as the economic situation in Russia changes. In this regard, the authors suggest continuing monitoring the behavior of the price for bread and other food products from the list of products for monitoring in chain and independent stores.

\section{References}

Aksoy, A., \& Isik-Dikmelik, A. (2008). Are low food prices pro-poor? Net food buyers and sellers in low-income countries. Policy Research Working Paper (p. 4642). Washington DC: World Bank.

Benson, T., Minot, N., Pender, J., Robles, M., \& Von, B. J. (2008). GLOBAL FOOD CRISES Monitoring and Assessing Impact to Inform Policy Responses. International Food Policy Research Institute Washington, D.C.

Bellemare, M. (2014). Rising Food Prices, Food Price Volatility, and Social Unrest. Retrieved March 23, 2015, from http://marcf bellemare.com/wordpress/wpcontent/uploads/2014/03/ BellemareAJAEFoodRiotsManuscript.pdf

Berazneva, J., \& Lee, D. R. (2013). Explaining the African Food Riots of 2007-2008: An Empirical Analysis. Food Policy, 39, 28-39.

Bush, R., (2010). Food Riots: Poverty, Power, and Protest. Journal of Agrarian Change, 10, 119-129.

Byerlee, D., Myers, R., \& Jayne, T. (2006). Managing Food Price Risks and Instability in an Environment of Market Liberalization. Agriculture and Rural Development Department. The World Bank: Washington, D.C.

Coissard, S., \& Seigli, C. (2011). Pricing with Monitoring Costs. Brussels Economic Review, 54(4).

Cuesta, J., Htenas, A., \& Tiwari, S. (2014). Monitoring global and national food price crises. Food Policy (Vol. 49, pp. 84-94)

Efimova, D., Lopatinskaya, I., Kaderova, V., \& Sidorchuk, R. (2015). Parametric approach to the assessment of service quality attributes of municipal passenger transport in Moscow. Modern Applied Science, 9(4), 303-311.

Fox, K. F.A., Skorobogatykh, I. I., \& Saginova, O. V. (2005). The Soviet evolution of marketing thought, 1961-1991: From Marx to marketing. Marketing Theory, 5(3), 283-307.

Fox, K. F. A., Skorobogatykh, I. I., \& Saginova, O. V. (2008). Philip Kotler's influence in the Soviet Union and Russia. European Business Review, 2, 152-176.

Ivanic, M., \& Martin, W. (2008). Implications of Higher Global Food Prices for Poverty in Low income countries. Draft Working Paper. Mimeographed.

Ivanic, M., \& Martin, W. (2014). The Welfare Effects of Changes in Food Prices, Trade Policy and Food Security: Improving Access to Food in Developing Countries in the Wake of High World Prices. Retrieved from http://dx.doi.org/10.1596/978-1-4648-03055_ch5

Kiseleva, T., Kiselev, V., Bastron, E., \& Kerimova, R. (2014). Factor Analysis of Consumer Value Spirits. Food Products Quality (pp. 5768). Cracow, Poland: Cracow University of Economics.

Kiselev, V. (2003). The state of the retail food trade (for example Kemerovo). Practical Marketing, 9(79), 19-34.

Ravallion, M. (1989). "Do Price Increases for Staple Foods Help or Hurt the Rural Poor ."PPR working Paper WPS. Washington D.C.: World Bank.

Schneider, M. (2008). "We Are Hungry!"-A Summary Report of Food Riots, Government Responses, and States of Democracy in 2008. Working Paper. Department of Development Sociology, Cornell University.

Seshan, G., \& Umali-Deininger, D. (2007). Agriculture and Import Liberalization and Household Welfare in Sri Lanka. Mimeographed.

Sidorchuk, R. (2015). The Concept of "Value "in the Theory of Marketing. Asian Social Science, 11(9), 320-325.

Poverty and inequality in modern Russia: 10 Years Later (2013), Russian Academy of Sciences, Institute of Sociology. Retrieved February 03, 2015, from http://www.isras.ru/files/File/Doklad/Analit_doc_Bednost/full.pdf

Rosstat. Retrieved February 03, 2015, from: http://www.gks.ru/dbscripts/cbsd/DBInet.cgi?pl=1921002

Rating network of retail trade. Retrieved January 03,2015 , from http://infoline.spb.ru/infoline-retailer-russia-top-100/index.php

Department of Trade and Services of Moscow. Retrieved January 03, 2015, from http://dtu.mos.ru/downloads/\%D0\%BD\%D0\%B0\%20\% D1\%81\%D0\%B0\%D0\%B9\%D1\%82\%2012\%20\%D0\%BC\%D0\%B5\%D1\%81\%202013.pdf 